\title{
THE DIARY GENRE IN THE DESCRIPTION OF ANTI-IMPERIAL IDEAS IN THE UKRAINIAN LITERATURE OF THE XVIII CENTURY
}

\author{
Velychkovska Yuliia \\ PhD Student \\ ORCID ID 0000-0003-4560-6447 \\ SHEI «Pereiaslav-Khmelnytskyi Hryhoriy Skovoroda State Pedagogical University» \\ 30, Sukhomlynskyi Str., Pereiaslav-Khmelnytsky, Kyiv Reg., 0840, Ukraine \\ y.velychkovska@ukr.net
}

The article deal the general patterns and main trends in the formation and development of the genre of diary as a self-sufficient form in the national literature in the XVIII century, in the coverage of anti-imperial ideas on the example of memoirs "Home Protocol" (1717-1767) of General Treasurer Yakov Markovich, "Diary or Journal" (1722) and "Diary" (1727 - 1752) of General Cornet Nikolai Khanenko. Analyzes the special approach of J. Markovych and M. Khanenko to the creation of the diary genre. It is proved that the memoirs are characterized by a special manner of narration, reminiscent of a clerical reporting document. The authors described events from their own lives, intertwining them with national ones. Fixing the moments with inherent factual accuracy helped to create a holistic canvas of our history during the period of the development of imperial colonial policy in Ukraine. An important feature of the diary narrative is the conciseness and introversion of the narrative, which is explained by the concealment of independent comprehension and assessment of events by diaries. The social level of everyday poetics emphasized the colonial position of Cossack Ukraine in the eighteenth century. A systematic analysis of the genre features of the diaries "Home Protocol" by J. Markovych, "Diary or Journal" and "Diary" by M. Khanenko genre-wise and problematically interconnected with the Cossack chronicle, suggests that the superficial content of notes on historical events in Ukraine and abroad its boundaries, conciseness and introversion of the story, fixation of moments with factual accuracy, the intertwining of personal life events with national ones contributed to the establishment of anti-imperial themes in national literature, that influenced trends in national literature

Key words: diary, Ya. Markovich, M. Khanenko, historical and memoir prose, antiMoscow ideas, retrospective view.

\section{ЖАНР ЩОДЕННИКА В ОКРЕСЛЕННІ АНТИІМПЕРСЬКИХ ІДЕЙ В УКРАЇНСЬКІЙ ЛІТЕРАТУРІ ХVІІІ СТОЛІТТЯ}

\section{Величковська Юлія}

Аспірантка

ORCID ID 0000-0003-4560-6447

ДВНЗ «Переяслав-Хмельницький державний педагогічний університет імені Григорія Сковороди»

вул. Сухомлинського, 30, м. Переяслав-Хмельницький, Київська обл., 0840, Україна y.velychkovska@ukr.net

У статті досліджуються загальні закономірності й основні тенденції становлення та розвитку жанру щчоденника як самодостатнього виду в національній літературі у XVIII столітті, у висвітленні антиімперських ідей на прикладі мемуарів «Домашній протоколь» (1717-1767) генерального підскарбія Якова Марковича, «Діаріушъ или Журналъ» (1722) $i$ «Дневникъ» (1727 - 1752) генерального хорунжого

(C) Velychkovska Yu., 2020 
Миколи Ханенка. Проаналізовано особистий підхід Я. Марковича та М. Ханенка до творення жанру щзоденника. Доведено, щчо мемуарні праці ичих канщеляристів характеризуються особливою манерою оповіді, щзо нагадує канцелярський звітний документ. Автори описували $i$ події із власного життя, переплітаючи їх із загальнонаціональними. Фіксація миттєвостей із притаманною фактографічною точністю допомогла створити цілісне полотно нашої історї у період розгортання $i$ наступу імперської колоніальної політики в Україні. Важливою рисою щчоденниковоі оповіді є лаконічність та інтровертність оповіді, щзо пояснюється приховуванням самостійного осмислення та оцінок подій щуоденникарями. Суспільний рівень тематики повсякденності підкреслював колоніальне становище Козацької Украӥни у ХVIII столітті. Системний аналіз жанрових особливостей щуоденників "Домашній протокол» Я. Марковича, "Діаріуш або Журнал» $i$ «Дневник» М. Ханенка, жанрово та проблемно взаємопов'язаних із козацьким літописанням, дає підстави стверджувати, щзо зміст нотаток про історичні події в Украӥні першої половини та середини ХVIII cm. і поза ї̈ межами, лаконічність та інтровертність оповіді, фіксація миттєвостей із фактографічною точністю, переплетіння особистісних життєвих подій із загальнонаціональними сприяли утвердженню в них антиімперської тематики, щь впливала й на тендениії в національній літературі.

Ключові слова: щзоденник, Я. Маркович, М. Ханенко, історико-мемуарна проза, антимосковські ідеї, ретроспективний погляд.

\section{Вступ}

Українська щоденникова проза, що довгий час залишалася поза належною увагою дослідників історії національного давнього письменства, дотична до числа найважливіших джерел «увічненого людського досвіду, до того ж не позбавленого яскравих літературних рис» (Зінченко, 2017: 37). Варто погодитися із думкою С. Єфремова, який підкреслив, що «форма щоденних записок здавна була відома на Україні і під назвою діаріушів здобула собі геть таки широкого розповсюдження серед письменних людей у старовину» (Сфремов, 1927, Т. 4: 13). Дослідник наголосив, що ця «інтимна форма записок про щоденне життя однієї людини має зв'язок з літописанням старого часу, з літописною літературною формою» (Сфремов, 1927, Т. 4: 13), оскільки літописи подають інформацію про події із року в рік. Джерелами українського щоденника $\epsilon$ перекладні візантійські історичні хроніки Іоана Малали, Георгія Амартола, Георгія Синкелла, що відомі були в літературі доби Київської Русі, а також у літописах тієї пори (Зінченко, 2017: 39). Особливістю цих мемуарних творів стало те, що їхні творці, за зауваженням О. Зінченко, зосереджувалися не на власній особі, а на подіях, котрі відбувалися навколо (Зінченко, 2017: 29), чим підкреслювали своє загальнонаціональне значення та зв'язок із літописною традицією. Друга половина XVII ст. пов'язує національну літературу із жанром щоденника, особливістю якого стає зосередження уваги на життєписі автора. Жанр щоденника починає відрізнятися від літописів сферою зацікавлень, «але форма та ж самісінька, тільки до нового матеріалу пристосована» (Єфремов, 1927, Т. 4: 14).

У першій половині XVIII століття жанр щоденника, за висновком М. Грушевського, стає частиною «літератури канцеляристів», що ставила перед собою завдання обгрунтувати правомірність поглядів козацької старшини на Україну, як свою законну Вітчизну та спадкоємницю Київської Русі. Поряд зі щоденниками Димитрія Туптала, Пилипа Орлика, Іллі Турчиновського, Йоасафа Горленка, П. Борзаківського та П. Ладинського, П. Апостола чільне місце посідають «Домашній протоколъ» (17171767) генерального підскарбія Якова Марковича, «Діаріушъ або Журналъ» (1722) i «Дневникъ» (1727 - 1752) генерального хорунжого Миколи Ханенка, що створені у період протистояння гетьманської влади руйнівним наступам московських імперіалістів, очолених Петром I.

Частковим дослідженням мемуарного твору «Домашній протоколъ» Я. Марковича займалися історики О. Лазаревський, В. Модзалевський, О. Апанович, О. 
Струкевич, а також літературознавці М. Корпанюк, П. Білоус, О. Зінченко. Дослідження мемуарів «Діаріушъ або Журналъ» і «Дневникъ» М. Ханенка здійснене О. Лазаревським, В. Бєлашовим, М. Корпанюком, П. Білоусом, О. Зінченко. Жанрова специфіка щоденникової прози проаналізована I. Франком, С. Єфремовим, О. Галичем, T. Бовсунівською, I. Сирко та ін. Запропонована студія дає можливість осягнути роль жанру щоденника в окресленні антимосковських ідей в українській літературі XVIII століття на прикладі мемуарів «Домашній протоколъ» Я. Марковича, «Діаріушъ або Журналъ» і «Дневникъ» М. Ханенка.

\section{Результати дослідження та їх обгрунтування}

Із перших десятиліть XIX століття щоденники як мемуарний жанр припиняють бути інтимним документом, з’являючись на сторінках періодичних видань («Чтения въ Императорскомъ обществђ исторіи и древностей россійскихъ», «Кіевская старина»). Поява мемуарної прози високо освічених людей свого часу відразу привернула до себе увагу не тільки української інтелігенції, а й московітів, які всіляко сприяли вилученню художньо-історичних праць із наукового обігу (цензурні обмеження). Причиною такої пильної уваги до щоденників стало те, що вони, за влучним зауваженням М. Корпанюка, є синкретичними жанрами, в яких переплетені військова, політична, господарсько-економічна, побутова тематики, класицистично-просвітницько-барокова стилістика та національний дух (Корпанюк, 2005: 469). Особливістю щоденників Я. Марковича та М. Ханенка є те, що вони, маючи відсутній наскрізний сюжет, делікатно торкаються злободенних проблем своєї сучасності, котрі безпосередньо були пов'язані $з$ колоніальною політикою московського уряду в Україні. Зауваження про антиколоніальний зміст мемуару «Діаріуш или журнал» М. Ханенка знаходимо у праці Павла Житецького «Энеида И. П. Котляревскаго и древньйшій списокъ ея» (1899), у якій автор запевняє, що в означеному щоденнику «сквозь офиціальную сдержанность явственно проглядываютъ политическія симпатіи его къ стариннымъ правамъ и вольностямъ малороссійскаго народа» (Житецькій, 1899, №12: 286). У передмові до видання щоденника Я. Марковича видавець О. Лазаревський зазначив: «Политическій элементь въ дневникъ М-ча [Якова Марковича. - Ю. В.], какъ уже сказано, незначителенъ, быть можетъ по причинь особой осторожности автора, усвоенной имъ, кажется, посль тревожныхъ годовъ Полуботковой исторіи» (Лазаревскій, 1893: 2). Завуальоване зауваження О. Лазаревського про наявність політичного спрямування мемуарного твору було надзвичайно актуальним для другої половини XIX ст., що ознаменувалося жорстокими імперськими колоніальними утисками українців Миколою I та цензурною політикою Олександра II. На противагу щоденникам Я. Марковича та М. Ханенка, мемуарний твір «Дневникъ гетманской канцеляріи за 1722 - 23 годы» зберіг ухвалені українським урядом постанови, розпорядження, інструкції, промеморії, укази, а також урядові листи, надіслані до різних інстанцій та установ у період обмеження царським урядом політичної автономії Лівобережної України. «Діаріушъ или Журналъ» генерального хорунжого став своєрідним, хоч і неопосередкованим, продовженням офіційного концелярсько-урядового щоденникадіарія.

Хронічка Павла Полуботка, що стала основою щоденника «Домашній протокол» Я. Марковича, окрім опису епізодів із минулого, вміщує в собі лаконічну фіксацію історичних подій за місяцями та роками від 1717 р. до 20 лютого 1723 р., спрямованих на узагальнення ключових етапів колонізації України Петром І. Стиль цих нотаток нагадує літописну традицію, вказуючи на взаємозв'язок із козацьким літописанням. Ретроспективний погляд дозволяє висвітлювати в новому ракурсі вже відомі, а також приховані факти колонізації рідного краю, «визначає свого роду історизм його загального погляду» (Татарковский, 1980: 31). Варто завважити, що до 10 жовтня 1723 p. (дата ув'язнення П. Полуботка) гетьман продовжував занотовувати у щоденнику інформацію про жорстоку імперську колонізацію України (руйнування Батурина, направлення козаків на будівельні роботи та воєнні походи). Відсутність записів від 
лютого до жовтня пояснюється тим, що зять Полуботка «ко времени приђзда А. И. Румянцева, въ 1723 г., на сльдствіе въ Малороссію, М-чъ [Яков Маркович. - Ю. В.] вырываетъ изъ этого дневника нъсколько листовъ, боясь конечно, что царській сльдователь можеть и до дневника добратися» (Лазаревскій, 1893: 14). Ця подія і вплинула на стилістичний та тематичний зміст щоденника «Домашній протокол», автор якого із 1723 р. «рисуетъ намъ ежедневную, будничную жизнь малорусскаго пана прошлаго стольтія» (Лазаревскій, 1893: 14). Ця ж особливість фіксації суспільних подій притаманна і щоденникам М. Ханенка, який був висланий П. Полуботком до Петербургу домагатися дозволу на обрання гетьмана. П. Житецький, аналізуючи щоденник генерального хорунжого, наголосив, що він, як прибічник ув'язненого гетьмана, «распустился въ прозђ жизни, отмъчая изо дня въ день текущія мелочи ея съ пунктуальностью человъка, привыкшаго къ канцелярскимъ формальностямъ» (Житецькій, 1899, №12: 286). Така особливість записів цілковито відповідає жанрові щоденника, для якого характерною $\epsilon$ «фрагментарність, що виражається у безсистемній фіксації подій, вражень, емоцій» (Ізотова, 2015, №3: 94).

Щоденникові нотатки Я. Марковича, М. Ханенка, як урядовців козацької старшини, залишилися невіддільні від державницьких проблем тодішньої України, що розвивалася під упливом імперського колоніалізму з другої половини XVII ст. Автори зафіксували й зберегли для історії нації факти внутрішньої політики та міжнародних зв'язків гетьманів І. Скоропадського, П. Полуботка, Д. Апостола, К. Розумовського, відомості 3 історії, побуту різних верств населення, розвитку ринку та ремесел упродовж 50 років (1717-1767).

Записи із хронічки Павла Полуботка, котрі відкривають мемуарну працю Якова Марковича, вказують на розгалуження московських наступальних колоніальних дій в Україні відразу після смерті Богдана Хмельницького, чим створюють визначальний момент у композиційному плані всього твору. Полуботкові нотатки надають його зятеві різноманітнішу та повнішу поживу для вражень та осмислення історичних подій, безпосередньо пов'язаних із колонізацією України. Стиль записів, що є подібним до літописних оповідей, розкриває перед читачами антиколоніальні виступи українців на чолі з гетьманами: «Подъ Конотопомъ була битва» (Маркович, 1893: 2); «Мазепа змънилъ» (Маркович, 1893: 4), а також поступову втрату нашої державності: «Гетманъ Брюховецкый на Москву ездиль и, оженившися тамъ, зъ великымъ жалованемъ повернулся» (Маркович, 1893: 2); «Воеводи стали по украинскыхъ городах» (Маркович, 1893: 2); «Многогрђшного на Москву взято» (Маркович, 1893: 2); «король шведскый зъ Мазепою въ малолюдстві утькъ до Бендеру» (Маркович, 1893: 4). Автор не вдається до коментування подій, знову ж таки, дотримуючись критерію літописання - відсторонена оповідь. На зв'язок із бароковими традиціями вказує нотатка Я. Марковича за 1715 р., в якій повідомляється, що «Въ Глуховъ въ мъсяцю марту 13 числь, упалъ верхъ церкви святой Тройци мурованой, въ день по полудню» (Маркович, 1893: 2). Оскільки, Троїцький собор був зведений козаками та місцевими жителями в 1657 році дерев'яним, а лише у 1720 році було ухвалено рішення про його перебудову з цегли, то занотовану інформацію про крах верха «церкви святой Тройци мурованой» (Маркович, 1893: 2) варто сприймати символічно. Цікавим є той факт, що у цій церкві за наказом Петра I 9 листопада 1708 року Івана Мазепу було піддано анафемі. Я. Маркович, дотримуючись барокових традицій символічності оповіді, зауважує про падіння гетьманського уряду I. Мазепи. Церква й надалі залишилась стояти, тобто українці нікуди не зникли, натомість «упалъ верхъ церкви» (Маркович, 1893: 2) - Україна залишилась без державного очільника. Цей епізод насичує жанр щоденника художньою тропікою, не властивою мемуарним творам попередніх століть. Я. Маркович подає «власну суб’єктивну концепцію дійсності, котру він реалізує в мемуарах шляхом композиційного розміщення матеріалу, добору й розстановки фактів, їх естетичного освоєння» (Галич, 1991: 36). Доречним є висновок Ірини Сирко, що «щоденник втрачає особистісний характер і навіть за умови створення «для себе» не виключає можливості «оприлюднення» (Сирко, 2013, №4: 98), або ж 
розповсюдження серед імперських прибічників. Підтвердженням думки дослідниці виступає «Щоденник» Петра Даниловича Апостола, котрий був написаний маловідомою при імперському дворі французькою мовою. Із запису М. Ханенка, датованого 18 грудня 1732 р., стає зрозуміло, що він був наближеною особою до імперського двору: «Рано были у ея высочества государини цесаревны Елизаветы Петровны зъ поздравленіемъ рожденіемъ ея высочества и къ ручкъ пожалованы» (Ханенко, 1884: 86). На відміну від інших нотаток, цей запис насичений зменшувально-пестливою інтонацією, стилістичним засобом метонімії («къ ручкь пожалованы» (Ханенко, 1884: 86)), що відбили проблему тогочасної поведінкової політики лакейства при імперському дворі та зверхність до всього людського. Проблема вірнопідданого прислужництва імперському урядові виринає у записах Я. Марковича та М. Ханенка, здійснених в осердях Російської імперії (Петербург, імперський двір), задля розмежування двох світів: українського та московського.

Зі щоденникових нотаток дізнаємося, що Яків Маркович був улюбленим студентом і щирим приятелем Теофана Прокоповича, а Микола Ханенко - довірена постать гетьманів I. Скоропадського та К. Розумовського. Мемуаристи не заперечують, що цим привілеєм вони користуються на власний розсуд. Знайомство із придворним імперським життям прищеплює військовим канцеляристам московську жагу до збагачення, про яку вони зауважують у нотатках. Розповідь про примноження земельних угідь, сіл, господарського майна, домашніх тварин та інвентарю, власного матеріального статку, купівля кріпаків свідчить про появу ознак жанру сповіді, що дає їм змогу по-новітньому дивиться на світ через глибоке самоусвідомлення і певну щирість. Як відомо, сповідь у відповідності з біблійними канонами $є$ шляхом до покаяння у своїх гріхах. Отже, варто узагальнити, що мемуаристи, розкриваючи власний шлях «набуття гріховності», відобразили пороки та вади козацької старшини, що піддалася московській колоніальній спокусі.

Попри обережність і канцелярську делікатність стилістичного мовлення Я. Марковича та М. Ханенка, все ж у їхніх щоденниках подано щедру інформацію про всебічну колонізацію України імперським урядом, що набуває рис проблематики мемуарного твору. Запис від 21 квітня 1722 р. у творі «Діаріушъ или Журналъ» генерального хорунжого повідомляє про створення Малоросійської колегії в Україні: «априля 19 состоялся въ сенать именный указъ о опредьленіи въ Малой Россіи коллегіи, въ которую назначенъ президентомъ Степанъ Лукичъ Вильяминовъ бригадиръ» (Ханенко, 1858: 22). Автор надає значну увагу презентативно відстороненому тлумаченню московських колоніальних дій в Україні, суголосну манері відвертості мемуару «Дневникъ гетманской канцеляріи за 1722 - 23 годы». В останньому знаходимо інформацію про суперечку між П. Полуботком та С. Вельміновим, що стала початком антиімперських виступів чернігівського полковника: «Былъ его м. п. полковникъ черньговскій [П. Полуботок. - Ю. В.] зъ старшиною енералною у г. бригадира [С. Вельямінова. - Ю. В.], где доволно дишкуруючи о зборахъ, якъ и о протчемъ, пробавили въ посидъню годинъ зо тры» (Лазаревский, 1898, Кн. 12, Отд. 3: 95). Генеральний підскарбій, на відміну від М. Ханенка, без наявної деталізації нотує, що у 1722 році «Колегія малороссійская устроена» (Маркович, 1893: 11). Недомовлений тип запису, притаманний жанрові щоденника, відмежовує працю Якова Марковича від стилю козацького літописання, вказуючи на появу нового підімперського писемного жанру - «щоденника канцеляриста». Щоденникарі втратили можливість «відкрито висловлювати свої думки, яка стала все відчутнішою після 1709 р.» (Історія української літератури, 2014, Т. 2: 721).

Обидва автори мемуарних творів звертають особливу увагу на фактичну достовірність описів колонізаторської політики Петра I та його наступників в Україні. Зокрема, у щоденнику М. Ханенка прочитуємо змістовно наповнену інформацію про вибори нового гетьмана в Україні лише із дозволу російського імператора: «Тайный совьтчикъ и міністръ Федоръ Василіевичъ Наумовъ [за наказом імператора Петра II. Ю. В.] отъехалъ зъ С. П. Бурха [Санкт-Петербурга. - Ю. В.] до Глухова для избранія 
гетмана» (Ханенко, 1884: 4). Проблема вимагання покори перед російськими імператорами від українців представлена у записах Я. Марковича: «Куріеръ зъ Пьтербурху пріехалъ и указъ привезль сюда зъ воинской коллегіи, дабы брегадиръ съ товарищами присягу виконали на върность ея величеству Государинђ імператрицъ» (Маркович, 1895: 204-205). Якщо ж не вдається приборкати козацьку Україну наказами, імперський уряд використовує підкупи соболевим хутром: «Пану гетману зъ колегіи иностранной принесено грамоту на гетманъство и шубу зеленую аксамитную, соболями подшитую» (Маркович, 1895: 247). Я. Маркович, розпочинаючи із 1723 р. (рік ув'язнення П. Полуботка), фіксує інформацію про примусове залучення козаків до будівельних робіт у Ладозі: «принесенъ указъ зъ С.-Питербурху [Санкт-Петербургу. Ю. В.] ... жебы 10 тисячей козаковъ до Ладоги ишло на робленне каналу, кроме кашеваровъ и тъхъ, которіе при обозу будуть» (Марковича, 1893: 11); «Виправили п. Данила Савущенка зъ указами, во всъ сотнъ, чтобъ виходили козаки въ ладожскую дорогу зъ поспьшеніемъ» (Маркович, 1893: 16). У щоденних записах М. Ханенка із притаманною канцелярською точністю піднято проблему участі козаків у будівельних роботах: «Получены указы о высылкъ 30 тысячъ работниковъ на льнійную работу, въ томъ числь зъ полку стародубского козаковъ 9 сотень лишкомъ, мужиковъ 2038, такожъ о постереганю, чтобъ люде не разыходились» (Ханенко, 1884: 42). Проблема використання козацьких полків у воєнних походах імператорів об'єктивно відображена генеральним хорунжим у занотованих інформативних повідомленнях: «Изволиль отъЂхать государ [Петро I. - Ю. В.] зъ Москви, забърая маршъ въ походъ до Астраханъ» (Ханенко, 1858: 27); «Грамота прислана къ ясневельможному [гетьману Данилу Апостолу. - Ю. В.] о виступленіи въ походъ» (Ханенко, 1884: 23). Проблема загибелі українських козаків ув іноземних краях відображена записами генерального підскарбія про ладозькі та дербентські походи імперських військ: «Листь правительскій ... о умершихъ въ Терку и Ладозђ козаках» (Маркович, 1893: 46); «въденіе о умершихъ козакахъ въ походахъ ладожскомъ и дербенскомъ прислано» (Маркович, 1893: 47). Проблему використання сировинно-продуктово-фуражних ресурсів України у власних імперських потребах піднято у щоденнику «Домашній протоколъ» Я. Марковича історично достовірно та чітко: «Зъ Украини, по указу царского величества Петра Первого, виставлено муки житной четвертей московскихь 30,000 и спроважено въ Смоленскъ подрадами ...» (Маркович, 1893: 10). Автор висвітлює також проблему створення військових поселень в Козацькій Україні: «... великороссійская армія новымъ образцемъ на зимовой квартири стала въ Украинъ» (Маркович, 1893: 10). Використання мемуаристом топоніму Україна свідчить про його патріотичну свідомість та прихильність до власного народу, його державності. Утвердження назви нашої держави звучить у нотатці М. Ханенка від 8 серпня 1745 р.: «... [відправлено I. Скоропадському. - Ю. В.] манускрипта объ Украинъ» (Ханенко, 1884: 351). Особливістю цих щоденних записів $\epsilon$ те, що автори, за висловом С. Єфремова, «ловлять події, мовляв, на гарячому вчинку, по свіжому зафіксовують їх сліду» (Єфремов, 1927, Т. 4: 15), малюючи картину суспільного буття нашого народу впродовж XVIII ст.

На сторінках щоденників Я. Марковича та М. Ханенка зібрані важливі відомості про розгортання антиколоніального процесу, представленого цікавістю української шляхти (Я. Лизогуб, В. Жураковський, А. Борзаківський, М. Ханенко, Я. Маркович, В. Гудович, С. Дівович) до написання компіляцій козацького літописання, як вкрай потрібної історії свого народу. Зокрема, Я. Маркович інформує, що гетьманові Кирилові Розумовському, «презентовали ему 3 книги: двђ Статута литовського по руску и полску печатне, третую - Статуты коронне, да трактатъ зъ Полщею 1686 году учиненный, которымъ уступлена полякамъ тогобочная Украина» (Дневник Я. Марковича, 1913: 262). Навколо гетьмана формується таємна організація, завданням якої було вирішування злободенних питань українців: «Рано ходилъ Гудовичъ къ графу Розумовскому съ челобитною, сочиненною о дълахъ малороссійскихъ ...» (Маркович, 1897: 324). Згуртувавши навколо себе освічену старшину, К. Розумовський 
запропонував реорганізувати адміністративний устрій Гетьманщини, ліквідувати митні побори (індикти та евекти), провести військову та судову реформи. Генеральні збори, як орган управління, які були скликані у Батурині у 1763 р., гетьман мав намір перетворити на такий собі шляхетський парламент, а гетьманську владу на монархічну, що відповідала європейському зразкові. Отже, Я. Маркович безпосередньо торкнувся проблеми зародження антиімперського спротиву в оточенні останнього українського гетьмана.

\section{Висновки та перспективи}

Характерною особливістю щоденників М. Ханенка та Я. Марковича є те, що вони, наслідуючи усталену в українському письменстві традицію мемуарної літератури (нерозривний зв'язок митця зі своїм історичним часом, переплетення особистісних життєвих подій із загальнонаціональними, безсистемна фіксація історичних миттєвостей iз фактографічною точністю, ретроспективний погляд на минуле, лаконічність та інтровертність оповіді, принцип панування індивідуального над безособовим, недомовлений тип запису), безпосередньо торкнулися висвітлення таких антиімперських проблем, як антиколоніальні виступи українців на чолі з гетьманами, втрата автономного статусу України, всебічна колонізація українських земель московським урядом, вимагання покори від українців перед російськими імператорами, підкупи української шляхти та гетьманів, збагачення козацької старшини, лакейство при імперському дворі, залучення козаків до будівельних робіт та їх участь у воєнних поход імператорів, загибель козаків в іноземних краях, використання сировинних ресурсів Козацької України, створення військових поселень в українських селах та містах, формування опозиції імперській політиці в Україні козацькою старшиною та гетьманським урядом. Розгляд щоденника крізь призму його жанрових особливостей відкриває перед істориками та літературознавцями перспективи дослідження ролі мемуарного твору у висвітленні антиколоніальних проблем в Україні XVIII ст.

\section{СПИСОК ВИКОРИСТАНИХ ДЖЕРЕЛ}

Апостол, 1895 - Апостол П. Дневникъ Петра Даниловича Апостола (1725-1727). Кіевская старина, 1895. Т. 50. № 7/8. С. 100-155.

Галич, 1991 - Галич O. A. Українська письменницька мемуаристика: природа, еволюція, поетика : монографія. Київ : КДПІ ім. О. М. Горького, 1991. 217

Галич, 2013 - Галич O. А. Щоденник як мемуарний жанр. Вісник Запорізького національного університету. №3. 2013. С. 31-36.

Єфремов, 1927 - Сфремов $С$. Передмова : Літературний автопортрет Шевченка. Шевченко, Тарас Григорович (1814-1861). Повне зібрання творів у 8 т. [Київ] : Держ. вид-во України, 1927. Т. 4 : Щоденні записки (журнал) / Ред. і вступ. сл. акад. С. Сфремова. С. 13-40.

Житецкій, 1899 - Житеиякій П. Энеида И. П. Котляревскаго и древнђйшій списокъ ея. Киевская старина. №12. 1899. С. 277-300.

Зінченко, 2017 - Зінченко О. «Домашній протокол» 1717-1767 рр. генерального підскарбія Якова Марковича в контексті українського щоденникарства XVIII ст. : дис. канд. філол. наук.: 10.01.01; НАН України, Ін-т літ ім. Т. Г. Шевченка. Київ, 2017. 187 с.

Ізотова, 2015 - Ізотова Н. П. Щоденник як форма психонаративу: ідеожанрові особливості (на матеріалі роману ЖД. М. Кутзее «In the neart of the contry»). Науковий вісник ДДПУ імені І. Франка. Серія «Філологічні науки». Мовознавство. № 3, 2015. С. 92-96.

Історія, 2014 - Історія украӥнської літератури: У 12 т. Київ: Наукова думка, 2014. Т. 2. $840 \mathrm{c}$. 
Корпанюк, 2005 - Корпанюк M. Слово. Хрест. Шабля (українське монастирськоцерковне, світське крайове літописання XVI-XVIII ст., компіляції козацького літописання XVIII ст. як історико-літературне явище. Київ : Смолоскип, 2005. 903 с.

Лазаревский, 1898 - Лазаревский А. М. Отрывки из дневника гетманской канцелярии за 1722-23 годы. Чтения в историческом обществе Нестора Летописца. Киевъ, 1898. Кн. 12. Отд. 3. С. 90-145.

Маркович, 1897 - Маркович Я. Дневникъ генерального підскарбія Якова Марковича (1717-1767 гг.). : [в 3 ч.] / под ред. Ал. Лазаревского. Киев : Тип. Г. Т. Корчак-Новицкого, 1893-1897. Ч. 1 : (1717-1725 гг.). 1893. 329 с.; Ч. 2 : (1726-1729 гг.). 1895.421 с.; Ч. 3. (1730-1734 гг.). 1897. 421 с.

Маркович, 1913 - Маркович Я. Дневник Якова Марковича рр. 1735-1740. Жерела до історії України-Руси. Том ХХІІ. / В. Модзалевський. Київ-Львів, 1913. 395 c.

Сирко, 2013 - Сирко I. M. Генеза жанру щоденника: історіографічний огляд. Українська мова. № 4. Київ, 2013. С. 93-102.

Франко, 1926 - Франко I. Додаткові томи до Зібрання творів у п’ятдесяти томах / редкол. : М. Г. Жулинський (голова) та ін. Київ: Наук. думка, 2010. Т. 54: Літературознавчі, фольклористичні, етнографічні та публіцистичні праці. 1896-1916 / ред. тому Є. К. Нахлік. 1216 с.

Ханенко, 1854 - Ханенко М. Діаріушъ или Журналъ. Чтения в обществе истории и древностей российскихъ. №1. 1858. 74 с.

Ханенко, 1884 - Ханенко М. Дневникъ генерального хорунжего Николая Ханенка. 1727-1753. Пріложеніе к журналу «Киевская старина». Київ, 1884. 514 с.

\section{REFERENCES}

Apostol, 1895 - Apostol P. D. Dnevnik (1895). Kievskaia starina (7/8), 100-155. [in Russian]

Halych, 1991 - Halych $O$. A. Ukrainska pysmennytska memuarystyka : pryroda, evoliutsiia, poetyka : monohrafiia. [Ukrainian literary memoirs: nature, evolution, poetics : monograph]. Kyiv : KDPI im. O. M. Horkoho, 1991. 217 s. [in Ukrainian]

Halych, 2013 - Halych O. A. Shchodennyk yak memuarnyi zhanr. [Diary as a memoir genre]. Visnyk Zaporizkoho natsionalnoho universytetu. №3. 2013. S. 31-36. [in Ukrainian]

Iefremov, 1927 - Iefremov Ye. Peredmova : Literaturnyi avtoportret Shevchenka. [Preface : Literary self-portrait of Shevchenko]. Shevchenko, Taras Hryhorovych (18141861). Povne zibrannia tvoriv u 8 t. [Kyiv] : Derzh. vyd-vo Ukrainy, 1927. T. 4 : Shchodenni zapysky (zhurnal) / Red. i vstup. sl. akad. S. Yefremova. S. 1340. [in Ukrainian]

Zhytetskii, 1899 - Zhytetskii P. Эneyda Y. P. Kotliarevskaho y drevnbishii spysokъ eia. [Kotlyarevsky's Aeneid and its ancient list]. Kyevskaia staryna. №12. 1899. S. 277-300. [in Russian]

Zinchenko, 2017 - Zinchenko O. «Domashnii protokol» 1717-1767 rr. heneralnoho pidskarbiia Yakova Markovycha v konteksti ukrainskoho shchodennykarstva XVIII st. ["Home Protocol" of 1717-1767 of the General Treasurer Yakov Markovych in the context of Ukrainian diary-making of the XVIII century.] : dys. kand. filol. nauk. : 10.01.01; NAN Ukrainy, In-t lit im. T. H. Shevchenka. Kyiv, 2017. 187 s. [in Ukrainian]

Izotova, 2015 - Izotova N. P. Shchodennyk yak forma psykhonaratyvu: ideozhanrovi osoblyvosti (na materiali romanu ZhD. M. Kutzee «In the neart of the contry»). [The diary as a form of psychonarrative: ideological genre features (based on the novel by JD M. Kutzee "In the neart of the contry")]. Naukovyi visnyk DDPU imeni I. Franka. Seriia «Filolohichni nauky». Movoznavstvo. № 3, 2015. S. 92-96. [in Ukrainian] 
Istoriia, 1867 - Istoriia ukrainskoi literatury. [History of Ukrainian literature]. Kyiv, 1867. Volume 1.539 p. [in Ukrainian]

Korpaniuk, 2005 - Korpaniuk M. Slovo. Khrest. Shablia (ukrainske monastyrsko-tserkovne, svitske kraiove litopysannia XVI-XVIII st., kompiliatsii kozatskoho litopysannia XVIII st. yak istoryko-literaturne yavyshche. [Word. Cross. Saber (Ukrainian monastic-church, secular regional chronicle of the XVI-XVIII centuries, compilations of the Cossack chronicle of the XVIII century as a historical and literary phenomenon.]. Kyiv : Smoloskyp, 2005. 903 s. [in Ukrainian]

Lazarevskyi, 1898 - Lazarevskyi A. M. Otryvky yz dnevnyka hetmanskoi kantseliaryy za 1722-23 hody. [Excerpts from the diary of the hetman's chancellery for 172223]. Chtenyia v ystorycheskom obshchestve Nestora Letopystsa. Kyiv, 1898. Kn. 12. Otd. 3. S. 90-145. [in Russian]

Markovych, 1897 - Markovych Ya. (Ed. Al. Lazarevskoho). Dnevnykъ heneralnoho pidskarbiia Yakova Markovycha (1717-1767 hh.). [Diary by the General Treasurer Yakov Markovich (1717-1767)]. : [3 ch.] : Typ. H. T. KorchakNovytskoho, 1893-1897. Ch. 1 : (1717-1725 hh.). 1893. 329 s.; Ch. 2 : (17261729 hh.). 1895. 421 s.; Ch. 3. (1730-1734 hh.). 1897. 421 s. [in Russian]

Markovych, 1913 - Markovych Ya. (Ed. V. Modzalevskyi). Dnevnyk Yakova Markovycha rr. 1735-1740. [Yakov Markovich's diary 1735-1740]. Zherela do istorii Ukrainy-Rusy. Tom XXII. Kyiv-Lviv, 1913. 395 s. [in Russian]

Syrko, 2013 - Syrko I. M. Heneza zhanru shchodennyka: istoriohrafichnyi ohliad. [The genesis of the genre of diary: a historiographical review]. Ukrainska mova. № 4. Kyiv, 2013. C. 93-102. [in Ukrainian]

Franko, 2010 - Franko I. (Ed. Ye. K. Nakhlik). Dodatkovi tomy do Zibrannia tvoriv u piatdesiaty tomakh. [Additional volumes to the Collection of works in 50 volumes] / redkol. : M. H. Zhulynskyi (holova) ta in. Kyiv : Nauk. dumka, 2010. T. 54: Literaturoznavchi, folklorystychni, etnohrafichni ta publitsystychni pratsi. 1896-1916. 1216 s. [in Ukrainian]

Khanenko, 1858 - Khanenko M. Diariush yly Zhurnal. [Diary or Journal]. Chtenyia v obshchestve ystoryy y drevnostei rossyiskykh. 1858. №1. 74 s. [in Russian]

Khanenko, 1884 - Khanenko M. Dnevnyk heneralnoho khorunzheho Nykolaia Khanenka. 1727-1753.[Diary by General Cornet Nikolai Khanenko. 1727-1753]. Prilozhenie k zhurnalu «Kyevskaia staryna». Kyiv, 1884. 514 s. [in Russian]

Received: 02 August, 2020 
